\title{
RESEARCH INTO GREENER TRANSPORTATION
}

\author{
R.M.G. Rajapakse
}

\begin{abstract}
This review paper summarizes the problems associated with transportation as regard to automobile emissions caused by fossil fuel combustion and ways of circumventing such problems. Hydrogen is perhaps the cleanest fuel though hydrogen in its molecular form is hardly available naturally. As such, current methods of hydrogen production and their problems will be revealed. Hydrogen production through water photo-splitting will then be thoroughly reviewed. Our work on the use of silver and niobium(v)-doped $\mathrm{TiO}_{2}$ in water photosplitting is then described. Silver nanoparticles deposited on $\mathrm{TiO}_{2}$ nanowires are capable of absorbing in the visible range due to surface plasmon resonance effect while $\mathrm{Nb}(\mathrm{V})$ introduces electronic energy levels within the band gap of titanium dioxide comparable to vibrational energy levels of titanium dioxide thus enabling absorption of infrared radiation and upconversion. This catalyst is perhaps the fasted water splitting catalyst designed and developed so far and is working even in the diffuse room light conditions and even in the dark. We then review fuel cell powered motor vehicles where we first give a brief introduction to fuel cells. In a fuel cell a fuel oxidizes by an oxidant and the latter is usually atmospheric oxygen. Both the fuel and air are supplied continuously for consistent performance. Oxygen reduction half-reaction is a difficult one involving over $500 \mathrm{mV}$ overpotential on many electrode surfaces. As such, electrocatalysts based on precious metals such as Pt-Rh are used as electrocatalysts for oxygen reduction which adds up to enormous cost of fuel cells. As such, ways of minimizing platinum content and the use of cheap nonplatinum catalysts will de described. The performance of large number of new catalysts which we developed will be reviewed by taking a few examples.
\end{abstract}

Keywords-greener transport, hydrogen energy, water photo-splitting, fuel cells, oxygen reduction electrocatalysts

\section{Introduction}

Clean food to eat, clean water to drink and clean air to breath are basic human needs. However, our struggle for the so-called better living standards contribute significantly to depriving of our own basic rights and basic needs as is very correctly indicated by the Great Native American Chief Seattle. The pollution of the environment; all segments including lithosphere, biosphere, hydrosphere and atmosphere, by anthropogenic origin, is considerable. Even the so called environmentally friendlier solar energy conversion to electricity, with the aid of silicon solar cells, which are now wide-spreading, are by no means green since the production of one tonne of solar grade silicon mandatorily emit over 1.5 tonnes of carbon dioxide gas to the atmosphere! [1] Our struggle for energy and the ever increasing demand for energy have hampered our environment in the highest possible adverse manner and fossil fuels used for transportation essentially stand out as a major source of air pollution.

R.M.G. Rajapakse

Department of Chemistry, University of Peradeniya, Peradeniya 20400, SRILANKA

Acknowledgements: Dr. K.G.C. Senarathna for carrying out fuel cell catalyst research and Mr. R.B.D.S. Rajapakse for Water Photosplitting research under my supervision.

\section{Hydrogen Energy}

Hydrogen gas is perhaps the cleanest energy resource available to humankind because the combustion of hydrogen gas produces water as the only product. As such, hydrogenfuelled motor vehicles are the environmentally friendliest means of transportation although, as of now, the cost of hydrogen-fuelled cars containing fuel cells are unaffordable to the common man simply due to their high cost. However, luxury cars such as Toyota Mirai, FCV Honda and Mercedes-Benz F-Cell are now in market. The Natural Abundance of Hydrogen in terms of mass of hydrogen per mass of Earth is $260 \mu \mathrm{g} / \mathrm{g}$ which means there are 6,700,000 $\mathrm{H}$ atoms per billion of all the atoms of the Earth [2]. The Oceans of the Earth contains $10.82 \%$ by mass of hydrogen. Petroleum and organic matter contain significant fraction of hydrogen but the atmosphere contains only minute amounts of hydrogen not in the form of hydrogen gas but due to the presence of water vapour. As such, hydrogen as hydrogen gas is virtually non-existent even in the atmosphere since hydrogen gas is capable of escaping our atmosphere due to its lightness and high speed thus making it enable to overcome the gravity pull. Currently, the majority of hydrogen gas is produced from fossil fuels by the process known as steam reforming of hydrocarbons or by partial oxidation of methane and coal gasification.

Only a small quantities of hydrogen gas is produced by other routes such as biomass gasification and electrolysis of water. The Production Capacity of Hydrogen in the United States alone is estimated to be over 11 million tonnes per year and nearly half is used on-site for oil refining and the rest is mainly used in the production of ammonia from nitrogen gas in the Haber Process and for the production of methanol by the reduction of carbon dioxide [3]. Water electrolysis is the splitting of water to hydrogen and oxygen gases using electricity and is by far the most expensive way of producing hydrogen gas due to the very high cost of electricity.

A smarter way to split water is not by using electricity directly in electrolytic cells but by using solar energy as energy source. Such Photocatalytic Water Splitting stands out to be very interesting subject if water can be split into hydrogen and oxygen gases just by suspending the catalyst in water and exposing the reactor to solar radiation. Photocatalytic Water Splitting belongs to an Artificial Photosynthetic Process theoretically requiring only water, photocatalyst and right kind of solar energy photons. The reaction can be shown as depicted in the following Equation. The reaction requires at least $1.23 \mathrm{eV}$ energy of photons (infrared photons) as per thermodynamic considerations but both half-reactions, i.e., oxidation of water to oxygen gas and reduction of water to hydrogen gas demand considerable overpotentials thus making huge kinetic barriers for the reactions to take place from a photocatalyst irradiated by infrared photons impossible. This process takes place naturally in complex biological pathways but industrial production of hydrogen gas is currently incompatible.

$$
2 \mathrm{H}_{2} \mathrm{O}(\mathrm{l}) \stackrel{\text { Photon Energy }>1.23 \mathrm{eV}}{\longrightarrow} 2 \mathrm{H}_{2}(\mathrm{~g})+\mathrm{O}_{2}(\mathrm{~g})
$$

Photocatalytic water splitting is stemmed from the discovery of Fujishima and Honda in 1974 [4] where they have demonstrated that ultraviolet light irradiated titanium dioxide electrodes are capable of producing oxygen and hydrogen from water. Since then innumerable efforts have been devoted on the photocatalytic splitting of water and numerous modifications have been effected. The use of 
nanoparticles of $\mathrm{TiO}_{2}$ in place of a flat sheet enabled a huge increase in surface area of the catalyst though the efficiencies obtained are still in the upper limit of a few micromoles per minute. $\mathrm{TiO}_{2}$ is a wide band gap semiconductor $\left(E_{g}=3.20 \mathrm{eV}\right)$ and the illumination of ultraviolet radiation of energy $\geq 3.20 \mathrm{eV}$ results in the excitation of valence band electrons to the conduction band $\left(\mathrm{e}_{\mathrm{CB}}{ }^{-}\right)$, thus creating positively charged lattice sites known as holes in the valence band, $\left(\mathrm{h}_{\mathrm{VB}}{ }^{+}\right)$. The majority of these electron-hole pairs thus generated undergo recombination generating heat and lower energy photons. Only a minute fraction is therefore available for useful redox reactions. The reaction scheme depicted below demonstrate these processes.

$$
\begin{aligned}
& \mathrm{TiO}_{2} \rightarrow \mathrm{h}_{\mathrm{VB}}^{+}+\mathrm{e}_{\mathrm{CB}}^{-} \\
& \mathrm{h}_{\mathrm{VB}}^{+}+\mathrm{e}_{\mathrm{CB}}^{-} \rightarrow \Delta+\mathrm{hu}^{\circ} \\
& 4 \mathrm{~h}_{\mathrm{VB}}^{+}+2 \mathrm{H}_{2} \mathrm{O} \rightarrow 4 \mathrm{H}^{+}+\mathrm{O}_{2} \\
& 4 \mathrm{e}_{\mathrm{CB}}^{-}+4 \mathrm{H}_{2} \mathrm{O} \rightarrow 4 \mathrm{OH}^{-}+2 \mathrm{H}_{2}
\end{aligned}
$$

$\mathrm{TiO}_{2}$ is by far the most studied photocatalyst for water splitting since the potential of the top of the $\mathrm{VB}$ of $\mathrm{TiO}_{2}$ is well below the standard electrode potential of water oxidation $(+1.23 \mathrm{~V}$ wrt SHE) and the bottom of the $\mathrm{CB}$ of $\mathrm{TiO}_{2}$ is well above the standard potential of $\mathrm{H}^{+}$reduction $(0$ $\mathrm{V}$ wrt SHE). Hence, on theoretical grounds, at least under standard conditions, the $\mathrm{h}^{+}-\mathrm{e}^{-}$pairs generated in $\mathrm{TiO}_{2}$ photocatalyst are able to split water to $\mathrm{O}_{2}$ and $\mathrm{H}_{2}$ gases [59]. Although, this is the case, the efficiencies of water splitting by solar energy irradiated $\mathrm{TiO}_{2}$ have been very low due to three reasons: (i) the band gap of $\mathrm{TiO}_{2}$ is large (3.20 $\mathrm{eV})$ so that only UV radiation of wavelength $\leqslant 380 \mathrm{eV}$ are effective which accounts only for $5 \%$ of the incident solar radiation on the Earth surface, (ii) majority of $\mathrm{h}^{+}-\mathrm{e}^{-}$pairs photogenerated undergo recombination very quickly generating heat and luminescence allowing only minute fraction to do useful half-reactions and (iii) very large and positive standard molar Gibbs Energy of Reaction (1) (+ 237 $\mathrm{kJ} \mathrm{mol}^{-1}$ ) making the backward reaction highly spontaneous [10]. In addition, the overpotentials required for oxidation of water to oxygen gas and reduction of water to hydrogen gas are considerably high thus demanding extra potentials for the reactions to proceed at appreciable rates thus making both reactions kinetically very slow at the above potentials. One way to extend the life-time of photogenerated $\mathrm{h}^{+}-\mathrm{e}^{-}$ pairs is to deposit islands of metal catalysts such as $\mathrm{Pt}, \mathrm{Au}$, $\mathrm{Pd}, \mathrm{Rh}, \mathrm{Ni}, \mathrm{Cu}$ or $\mathrm{Ag}$ on $\mathrm{TiO}_{2}$ nanoparticles [11-13]. The Fermi Levels of these metals are more negative than the potential of the bottom of $\mathrm{CB}$ of $\mathrm{TiO}_{2}$ nanoparticles and hence photogenerated electrons can be transferred to metal islands while holes remaining in the $\mathrm{VB}$ of $\mathrm{TiO}_{2}$ so as to separate the photogenerated $\mathrm{h}^{+}-\mathrm{e}^{-}$pairs. The metal deposition is indeed shown to improve the photocatalytic water splitting efficiency of $\mathrm{TiO}_{2}$ photocatalysts [14]. Use of sacrificial electron donors such as oxalic acid, methanol, formic acid, formaldehyde etc. were also shown to improve photocatalytic hydrogen generation efficiency of $\mathrm{TiO}_{2}$ since these substances are easier to oxidize than water [15-17]. Addition of carbonate salts to water has resulted in improved hydrogen generation due to the suppression of the back reaction [18]. Use of metals in the form of quantum dots (nanoparticles whose all three dimensions are confined to the nanoscale of $1 \mathrm{~nm}$ to $100 \mathrm{~nm}$ ) enables to harness sizedependent properties, particularly, size-dependent optical and electrical properties such as Surface Plasmon Resonance (SPR) [19].

Gold and silver quantum dots exhibit SPR in the visible range as exemplified by the versatile colours of these nanoparticles depending upon their size and shape. SPR enables the quantum dots to absorb in the visible region for electronic excitation. Since the Fermi Levels of these quantum dots are more negative than the potential of the bottom of the $\mathrm{CB}$ of $\mathrm{TiO}_{2}$ nanoparticles, the excited electrons in the quantum dots can be injected to the $\mathrm{CB}$ of $\mathrm{TiO}_{2}$ thus enabling increased water reduction to generate hydrogen [14].

The doping of $\mathrm{TiO}_{2}$ nanoparticles with various transition metal and f-block metal ions is another strategy that has been thoroughly investigated to create electronic energy levels within the band gap of $\mathrm{TiO}_{2}$ to enable the composite materials visible light responsive. The same could also be achieved by non-metal doping such as $\mathrm{N}$ - or S-doping of $\mathrm{TiO}_{2}$. Water splitting by these composite catalysts have also been thoroughly investigated. The nanostructure and the crystallographic phase of $\mathrm{TiO}_{2}$ have been found to influence crucially on the efficiency of $\mathrm{H}_{2}$ photogeneration $[15,16]$. However, the efficiencies so far achieved are below $1 \mathrm{mmol}$ of $\mathrm{H}_{2}$ gas per hour for continuous illumination of solar radiation. We have combined the advantages of perfectly engineered nanostructures of $\mathrm{TiO}_{2}$, quantum dots of silver deposited on the engineered nanostructure of $\mathrm{TiO}_{2}$ and $\mathrm{Nb}(\mathrm{V})$ doping to make a photocatalyst that is capable of generating hydrogen gas highly efficiently giving rise to about $3 \mathrm{~mL}$ per minute which is by far the most active photocatalyst ever discovered. We made use simple and low-cost sol-gel technique followed by hydrothermal treatment and the powerful self-assembly of nanomaterials to form engineered architectures of long and thin nanowires of $\mathrm{TiO}_{2} / \mathrm{Ag} / \mathrm{Nb}(\mathrm{V})$ photocatalyst which is grey-black in colour. The photocatalyst is capable of splitting distilled water when exposed to even stray light coming through the glass windows of the laboratory. This rate of water splitting is three orders of magnitude faster than the best recorded efficiency thus far. The fact that the catalyst is grey-black in colour and its ability to split water even under infrared irradiation suggest that the catalyst is capable of upconverting infrared photons to visible photons to aid in electronic excitations. The doping by $\mathrm{Nb}(\mathrm{V})$ has therefore introduced electronic energy levels within the band gap of $\mathrm{TiO}_{2}$ which are as close as the vibrational energy levels of $\mathrm{TiO}_{2}$. The catalyst is trifunctional in radiation absorption: UV absorption by $\mathrm{TiO}_{2}$ nanowires, Visible light absorption by $\mathrm{Ag}$ quantum dots and infrared absorption by doped $\mathrm{Nb}(\mathrm{V})$ ions. These collective radiation absorption and photon upconversion results in increased electron injection to the $\mathrm{CB}$ of $\mathrm{TiO}_{2}$ nanoparticles thus making the composite catalyst superior to everything else so far discovered. The self-assembled architecture of thin and long nanowires of $\mathrm{TiO}_{2}$ also influences positively towards efficient hydrogen generation. An SEM image of $\mathrm{Nb}(\mathrm{V})$-doped $\mathrm{TiO}_{2}$ nanowire/Ag quantum dot composite is shown in Figure 1. 
Proc. of The Seventh Intl. Conf. On Advances in Applied Science and Environmental Technology - ASET 2017 Copyright (C) Institute of Research Engineers and Doctors, USA .All rights reserved.

ISBN: 978-1-63248-136-8 doi: 10.15224/ 978-1-63248-136-8-47

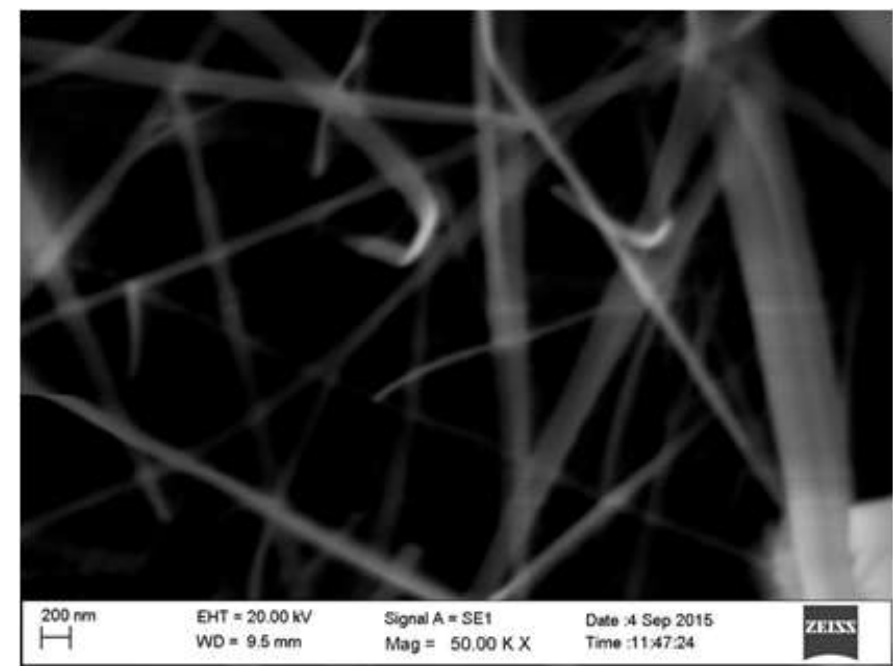

Figure 1: $\mathrm{SEM}$ image of $\mathrm{Nb}(\mathrm{V})$-doped $\mathrm{TiO}_{2}$ nanowires with silver quantum dot islands on them.

\subsection{Motor Vehicles Containing Internal Combustion Engines Utilizing Hydrogen Fuel}

2.1.1 Hydrogen fuelled internal combustion engines (ICEs) and hydrogen/oxygen fuel cells.

In fact, the first ICE that was produced in 1806 by Francois Issac de Rivaz ran on a hydrogen/oxygen mixture [20-21]. Only in 1970 the patent for the ICE powered by gasoline was obtained [22]. Tokyo City University is developing Hydrogen Fuelled Internal Combustion Engines (HFICEs) since 1970 and they have recently developed hydrogen fuelled bus and truck [23]. Mazda has developed Wankel engines that burn hydrogen. During the period from 2005 to 2007, BMW tested a supercar named the BMW Hydrogen 7, powered by a hydrogen ICE, which achieved $301 \mathrm{~km} / \mathrm{h}$ (187 $\mathrm{mph}$ ) in tests [23]. Alset $\mathrm{GmbH}$ developed hybrid hydrogen systems that allow vehicle to use petrol and hydrogen fuels individually or at the same time with an internal combustion engine. This technology was used with Aston Martin Rapide $S$ during the 24 hours Nürburgring race. The Rapide $S$ was the first vehicle to finish the race with hydrogen technology [23].

HFICEs require hardened valves and valve seats, strong connecting rods, non-platinum tipped spark plugs, high voltage ignition coil, fuel injector designed for a gas, large crankshaft damper, strong head gasket material, modified for supercharger intake manifold, positive pressure supercharger and high-temperature engine oil making them 1.5 times more costly to produce a HFICE than a normal gasoline ICE. Although, these engines are $\mathrm{CO}_{2}$ emission free when hydrogen is burnt with air at high temperatures various $\mathrm{NO}_{\mathrm{x}}$ gases are produced which are more harmful as greenhouse gases than $\mathrm{CO}_{2}[23]$.

\section{Fuel Cell Powered Motor Vehicles \\ 3.1 Fuel Cells in General}

Fuel cell is a device capable of converting chemical energy change of a net chemical reaction between a fuel and an oxidizer $\left(-\Delta G_{\text {reaction }}\right)$ to electrical energy (nFEcell). Net reaction takes place as two half-reactions at the two electrodes and hence fuel cells resemble Galvanic cells in many ways except that reactants are supplied externally to enable to maintain constant supply of reactants. As such, there is no depletion of reactants as they are replenished due to continuous supply. Both half-reactions demand catalysts and platinum is the catalyst of choice for both half-reactions and the oxygen reduction further demands $\mathrm{Rh}$ to prevent catalyst poisoning [24]. Fuel cells are an important enabling technology for the world's energy portfolio and have the potential to revolutionize the way we power. They offer clean and more-efficient alternatives to the combustion of gasoline and other fossil fuels. Fuel cells have the potential to replace the internal-combustion engine in vehicles and provide power in stationary and portable power applications because they are energy-efficient, clean, and fuel-flexible, particularly, for remote stations where National Grid is not available. Fuel cells offer power output in a vast range up to about $100,000 \mathrm{~kW}$ with much higher efficiencies than gasoline electric, diesel electric and steam and gas turbines. Although there are several different types of fuel cells, all of them except molten carbonate fuel cells utilize oxygen reduction at the cathode and many utilize oxidation of hydrogen at the anode although any other fuel such as methanol or any oxidizable organic material such as methane or any other hydrocarbon may be used.

\subsection{Electrocatalysts for Fuel Cells}

Out of the two half-reactions cathodic reduction of oxygen gas demands a higher overpotential and hence research efforts are diverted towards increasing cathodic activity and durability by modifying platinum catalysts or developing new catalysts with the aim of reducing cost of catalysts also. Research efforts are being carried out with for strategic plans: (i) to lower platinum group metal (PGM) content by catalyst engineering particle morphology and crystal structure [25], (ii) alloying Pt with less expensive base metals such as $\mathrm{Co}, \mathrm{Mn}, \mathrm{Ni}$, and others [26-28], (iii) developing novel supports such as non-carbon supports and alternative carbon structures [29-30] and (iv) developing non-PGM catalysts. Major progress in the electrocatalyst and support area has been made. As for particle engineering, the knowhow of nanotechnology has been utilized in developing Pt nanoparticles with extremely high surface area deposited on carbon or S/N-doped carbon supports. Several researchers have demonstrated that $\mathrm{Pt}$ alloy compositions have significantly higher performance and durability than Pt alone. A total Pt-loading of $0.4 \mathrm{mg} \mathrm{Pt} / \mathrm{cm}^{2}$ has been demonstrated in a single cell for more than 7,300 hours with voltage cycling, surpassing the 2015 durability targets [31]. As for non-carbon supports, an example of a non-carbon catalyst support is 3M's nanostructured thin film polymer whisker concept as well as titanium dioxide (Aldrich Prod. No. 14021) and tungsten carbide (Aldrich Prod. No. 241881)

We have been pioneered in developing non-Pt catalysts for the oxygen reduction half-reaction (ORR). We developed an extremely clay-polymer catalyst [montmorillonitepolypyrrole-Ce(III), MMT-PPY-Ce(III)] that is capable of reducing oxygen to hydroxyl ions via 4-electron pathway that is required for fuel cell applications. This was published in Electrochimica acta in 2010 [32]. This work has been reviewed in a book [33]. We have now developed several other systems based on Montmorillonite clay/Electronically 
Conducting Polymer/Reduced Form of the Oxidative Metal Cation Composites to replace prohibitively expensive $\mathrm{C} / \mathrm{Pt}$ used as oxygen reduction catalysts in fuel cells. In this respect, we developed a large number of such catalysts; namely, MMT/PPY/Ce(III), MMT/PANI/Ce(III), MMT/PEDOT/Ce(III), MMT/PANI/Ag(0), MMT/PPY/Ag(0), MMT/PEDOT/Ag(0), MMT/PPY/Fe(II), MMT/PANI/Fe(II),

$\mathrm{MMT} / \mathrm{PPY} / \mathrm{Hg}(0)$,

$\mathrm{MMT} / \mathrm{PEDOT} / \mathrm{Hg}(0)$,

$\mathrm{MMT} / \mathrm{PANI} / \mathrm{Co}(\mathrm{II})$,

$\mathrm{MMT} / \mathrm{PEDOT} / \mathrm{Fe}(\mathrm{II})$

$\mathrm{MMT} / \mathrm{PANI} / \mathrm{Hg}(0)$,

$\mathrm{MMT} / \mathrm{PPY} / \mathrm{Co}(\mathrm{II})$, MT/PPY/Pd(0), MMT/PANI/Pd(0), MMT/PEDOT/Pd(0), where MMT, PPY, PANI and PEDOT have their usual meanings of montmorillonite, polypyrrole, polyaniline and poly(thylenedioxythiophene). We have also developed other systems such as $\mathrm{Pd} / \mathrm{C}, \mathrm{Pd} / \mathrm{CNT}, \mathrm{Pd} / \mathrm{C} / \mathrm{PPY}$, $\mathrm{Pd} / \mathrm{CNT} / \mathrm{PEDOT}$, Pd/Graphene and so on. All these materials were extensively characterized by XRD, SEM, EDAX, FT-IR, XPS and thermal analytical techniques. Their electrical conductivities and other electrical parameters were elucidated through DC-Conductivity measurements, AC-Impedance Analysis and Cyclic Voltammetry. Their catalytic activities towards oxygen reduction have been measured by cyclic voltammetry, linear sweep voltammetry and by rotating disc voltammetry. Some of the catalysts which we have developed were found to be superior to highly expensive $\mathrm{C} / \mathrm{Pt}$ catalysts at the same amount of catalyst loading. Pd/CNT/PEDOT catalyst is highly methanol tolerant and therefore is an excellent lowcost electrocatalyst for direct methanol fuel cells. A comparison of electrocatalytic activities of $\mathrm{Co}(\mathrm{II}) / \mathrm{MMT} / \mathrm{PPY}, \mathrm{Co}(\mathrm{II}) / \mathrm{MMT} / \mathrm{PEDOT}, \mathrm{C} / \mathrm{Pt}$ and $\mathrm{GC}$ electrodes towards oxygen reduction half reaction is exemplified in Figure 3 where rotating disc voltammetric studies in $\mathrm{O}_{2}$-purged $0.10 \mathrm{M} \mathrm{KOH}(\mathrm{aq})$ electrolyte solution are displayed [34]. Co(II)/MMT/PANI, Co(II)/MMT/PPY and $\mathrm{Co}(\mathrm{II}) / \mathrm{MMT} / \mathrm{PEDOT}$ have electrical conductivities of $0.38 \mathrm{~S} \mathrm{~m}^{-1}, 0.78 \mathrm{~S} \mathrm{~m}^{-1}$ and $0.32 \mathrm{~S} \mathrm{~m}^{-1}$ respectively, showing their usefulness as electrocatalysts.

Koutecky-Levich plots, drawn for different voltage values which were obtained from their polarization curves, for $\mathrm{Co}(\mathrm{II}) / \mathrm{MMT} / \mathrm{PEDOT}$, are shown in the Figure 3. electrons transferred (n) through the $\mathrm{Co}(\mathrm{II}) / \mathrm{MMT} / \mathrm{PEDOT}$ electrocatalytic reaction was then determined using the slop of the plots and the kinetic currents were obtained using the intercept of the graphs. The plots are parallel to each other hence all of them have the same $n$ value of 3.2 and is close to 4 . By using the Koutecky-Levich plots, the number of Hence the material shows good catalytic properties even at lower over potential values where oxygen is reduced to hydroxyl ions through 4-electron pathway that is required in fuel cell applications. This system is of very low cost and superior to $\mathrm{C} / \mathrm{Pt}$ at same mass loading.

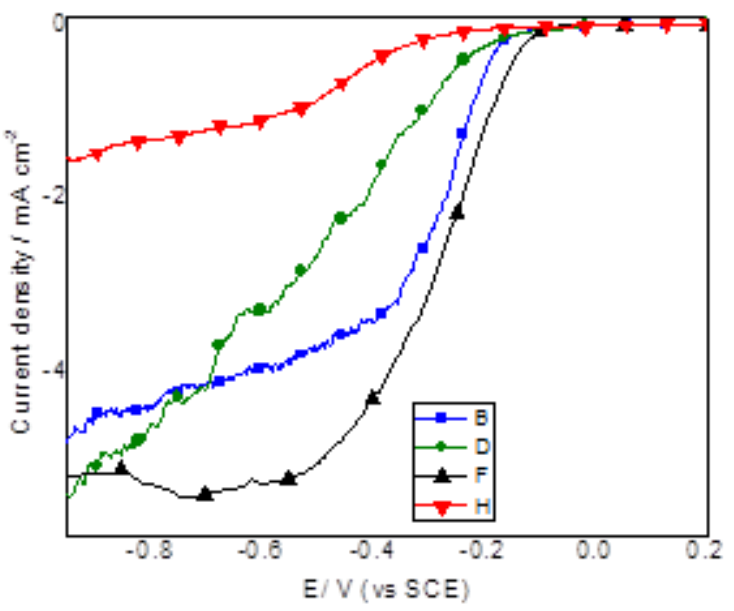

Figure 2: Polarization curves of $\mathrm{Co}(\mathrm{II}) / \mathrm{MMT} / \mathrm{PPY}$ (B), Co(II)/MMT/PEDOT (F), Pt/C (D) and GC (H) electrodes at a rotation rate of $1600 \mathrm{rpm}$ and a scan rate of $5 \mathrm{mV} \mathrm{s}^{-1}$ in oxygenated $0.10 \mathrm{M} \mathrm{KOH}(\mathrm{aq})$ Electrolyte.

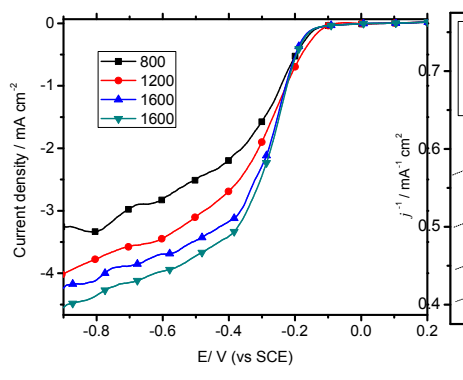

(a)

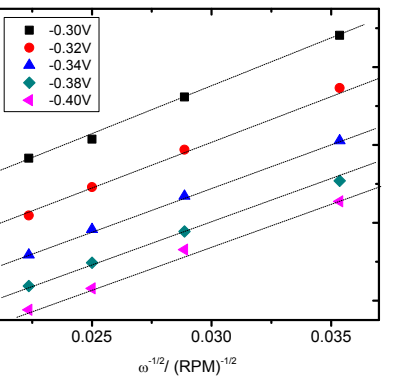

(b)
Figure 3: (a) Polarization curves of $\mathrm{Co}(\mathrm{II}) / \mathrm{MMT} / \mathrm{PEDOT}$ obtained at different rotating rates. (b) Koutecky-Levich plots of $\mathrm{Co}(\mathrm{II}) / \mathrm{MMT} / \mathrm{PEDOT}$ at different potentials.

\section{References}

[1] R. Castellano, "Solar Panel Processing," Old City Publishing Inc., Philadelphia, USA, 2010.

[2] M. Uehling, The Story of Hydrogen. New York: Franklin Watts, 1995.

[3] The Essential Chemical Industry Online, Hydrogen, http://www.essentialchemicalindustry.org/chemicals/hydrogen.html Copyright $\odot 2017$ CIEC Promoting Science at the University of York, York, UK..

[4] A. Fujishima and K. Honda, "Electrochemical Photolysis of Water at a Semiconductor Electrode," Nature, 238, 37-38 (07 July 1972); doi:10.1038/238037a0.

[5] M. R. Hoffmann, S. T. Martin, W. Choi, and D. W. Bahnemann, "Environmental applications of semiconductor photocatalysis," Chemical Reviews, vol. 95, no. 1, pp. 69-96, 1995.

[6] M. Anpo and M. Takeuchi, "The design and development of highly reactive titanium oxide photocatalysts operating under visible light 
irradiation," Journal of Catalysis, vol. 216, no. 1-2, pp. 505-516, 2003.

[7] Y. Shiraishi, H. Sakamoto, Y. Sugano, S. Ichikawa, and T. Hirai, "Pt$\mathrm{Cu}$ bimetallic alloy nanoparticles supported on anatase $\mathrm{TiO}_{2}$ : highly active catalysts for aerobic oxidation driven by visible light," ACS Catalysis, vol. 7, pp. 9287-9297, 2014.

[8] C. Nwosu, "An electronegativity approach to catalytic performance," Journal of Technical Science and Technologies, vol. 1, pp. 25-28, 2012.

[9] W. Gao, J. Chen, X. Guan, R. Jin, F. Zhang, and N. Guan, "Catalytic reduction of nitrite ions in drinking water over $\mathrm{Pd}-\mathrm{Cu} / \mathrm{TiO}_{2}$ bimetallic catalyst," Catalysis Today, vol. 93-95, pp. 333-339, 2004.

[10] B. G. Kyle, Chemical and Processes Thermodynamics, 512 pp. Englewood Cliffs, NJ: PrenticeHall, 1984

[11] M. Bowker, C. Morton, J. Kennedy et al., "Hydrogen production by photoreforming of biofuels using $\mathrm{Au}, \mathrm{Pd}$ and $\mathrm{Au}-$ $\mathrm{Pd} / \mathrm{TiO}_{2}$ photocatalysts," Journal of Catalysis, vol. 310 , pp. 10-15, 2014.

[12] A. Gallo, M. Marelli, R. Psaro et al., "Bimetallic $\mathrm{Au}-$ $\mathrm{Pt} / \mathrm{TiO}_{2}$ photocatalysts active under UV-A and simulated sunlight for $\mathrm{H}_{2}$ production from ethanol," Green Chemistry, vol. 14, pp. 330-333, 2012

[13] P. V. Kamat, "Meeting the clean energy demand: nanostructure architectures for solar energy conversion," Journal of Physical Chemistry C, vol. 111, no. 7, pp. 2834-2860, 2007.

[14] A. Tanaka, K. Teramura, S. Hosokawa, H. Kominamic and T. Tanaka, "Visible light-induced water splitting in an aqueous suspension of a plasmonic $\mathrm{Au} / \mathrm{TiO}_{2}$ photocatalyst with metal co-catalysts, " Chem. Sci., 8, 2574-2580, 2017.

[15] Á. Kmetykó , K. Mogyorósi, V. Gerse, Z. Kónya, P. Pusztai, A. Dombi and K. Hernádi, "Photocatalytic $\mathrm{H}_{2}$ Production Using $\mathrm{Pt}_{-} \mathrm{TiO}_{2}$ in the Presence of Oxalic Acid: Influence of the Noble Metal Size and the Carrier Gas Flow Rate," Materials, 7, 7022-7038, 2014; doi:10.3390/ma7107022 and references therein.

[16] Mizukoshi, Y.; Makise, Y.; Shuto, T.; Hu, J.; Tominaga, A.; Shironita, S.; Tanabe, S. "Immobilization of noble metal nanoparticles on the surface of $\mathrm{TiO}_{2}$ by the sonochemical method: Photocatalytic production of hydrogen from an aqueous solution of ethanol", Ultrason. Sonochem., 14, 387-392, 2007.

[17] J.C Yang,. Y.C Kim,. Y.G Shul,. C.H Shin.. T.K. Lee, "Characterization of photoreduced $\mathrm{Pt} / \mathrm{TiO}_{2}$ and decomposition of dichloroacetic acid over photoreduced $\mathrm{Pt} / \mathrm{TiO}_{2}$ catalysts", Appl. Surf. Sci., 121, 525-529, 1997.

[18] K. Maeda, N. Murakami, and T. Ohno, "Dependence of Activity of Rutile Titanium(IV) Oxide Powder for Photocatalytic Overall Water Splitting on Structural Properties", J. Phys. Chem. C, 118 (17), pp 9093-9100, 2014. DOI: 10.1021/jp502949q

[19] L. Yan, F. Wang, and S. Meng, "Quantum Mode Selectivity of Plasmon-Induced Water Splitting on Gold Nanoparticles", ACS Nano, 10 (5), pp 5452-5458, 2016. DOI: 10.1021/acsnano.6b01840

[20] E. Eckermann, (2001). World History of the Automobile. Warrendale, PA: Society of Automotive Engineers. ISBN 0-7680-0800-X.

[21] US 7137366 Page 10: : In the early nineteenth century, Francois Isaac de Rivaz of Switzerland invented a hydrogen-powered internal combustion engine.

[22] US $3617034 \mathrm{~A}$, Internal combustion engine fuel system minimizing evaporative fuel losses, United States Patent Davis A. Skinner V Fullerton, Calif

[23]https://www.revolvy.com/main/index.php?s=Hydrogen\%20internal\%2 0combustion\%20engine\%20vehicle

[24] US Department of Energy: Fuel Cell Technologies Office, Progress and Accomplishments in Hydrogen and Fuel Cells, https://www1.eere.energy.gov/hydrogenandfuelcells/pdfs/accomplish ments.pdf

[25] M. Kalyva, D. S. Wragg, H. Fjellväg and A. O. Sjästad, "Engineering Functions into Platinum and Platinum- Rhodium Nanoparticles in a One-Step Microwave Irradiation Synthesis", ChemitryOPEN, 6, 273 28, 2017. DOI: $10.1002 /$ open.201600163

[26] US 6911278 B2, Electrode catalyst for fuel cell and process for producing the same, K. Hiroshima, T. Asaoka, Y. Ohya, T. Noritake, H. Kato, T. Nagami, Toyota Jidosha Kabushiki Kaisha, 28. June 2005.
[27] US 20110020735 A1, Fuel Cell Catalysts with Enhanced Catalytic Surface Area and Method of Making the Same, C. Paik, L. Xu, H. Jen, K. M. Adams, M. S. Sulek, S. A. Mueller, Jan 27, 2011

[28] US 20030054227 A1, Electrode catalyst for fuel cell and process for producing the same, K. Hiroshima, T. Asaoka, Y. Ohya, T. Noritake, H. Kato, T. Nagami, Mar 20, 2003.

[29] X. X. Wang, Z. H. Tan, M. Zeng and J. N. Wang, "Carbon nanocages: A new support material for $\mathrm{Pt}$ catalyst with remarkably high durability," Scientific Reports 4, Article number: 4437, 2014. doi:10.1038/srep04437

[30] N. Mansora, T. S. Millerb, I. Dedigamaa, A. B. Jorgec, J. Jiad, V. Brázdováb, C. Mattevid, C. Gibbse, D. Hodgsonf and P. R. Shearinga, Graphitic Carbon Nitride as a Catalyst Support in Fuel Cells and Electrolyzers, Review Article, Electrochimica acta, 222, 44-57, 2016 and references therein.

[31] 2008 Fuel Cells Summary of Annual Merit Review Fuel Cells Subprogram, https://www.hydrogen.energy.gov/pdfs/review08/4410705_fuel_cells.pdf

[32] R.M.G. Rajapakse, Kenji Murakami, H.M.N. Bandara, R.M.M.Y. Rajapakse, K. Velauthamurti and S. Wijeratne, "Preparation and Characterization of Electronically Conducting PolypyrroleMontmorillonite Nanocomposite and Its Potential Application as a Cathode Material for Oxygen Reduction”, Electrochimica Acta 55 2490-2497, 2010

[33] Advances in Research and Application: 2011 Edition by Q. A. Acton, PhD, Copyright@2012 Scholarly Edition^TM. ISBN: 978-1-46492064-9.

[34] K. G. C. Senarathna, H.M.S.P. Randiligama and R. M. G. Rajapakse, Preparation, Characterization and Oxygen Reduction Catalytic Activities of Nanocomposites of Co(II)/Montmorillonite Containing Polypyrrole, Polyaniline or Poly(Ethylenedioxythiophene), RSC Advances, Accepted, 2017.

About Author (s):

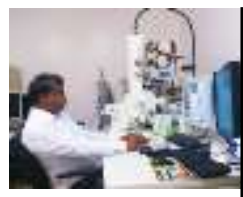

Professor R. M. G. Rajapakse (FNASSL) is a Senior Professor and the Coordinator of the M. Sc. in Nanoscience and Nanotechnology, University of Peradeniya, Sri Lanka. He holds a Ph. D. and D. I. C from Imperial College, London and worked at Imperial College, UMIST, Universities of Bath, Central Lancashire and Liverpool, UK, and Max Planck Institute for Polymer Research, Germany. He was a Visiting Scholar to University of Texas at Arlington, USA, and is a Visiting Professor to the Research Institute of Electronics, Shizuoka University, Japan and produced over 25 M. Phil. /Ph. D. Degrees, over 70 indexed publications, over 150 publications and six pending patents. 